\title{
Thermal Analysis on Cryogenic Liquid Hydrogen Tank on an Unmanned Aerial Vehicle System
}

Xiao-Yen Wang, George Harpster, and James Hunter

Glenn Research Center, Cleveland, Ohio 


\section{NASA STI Program . . . in Profile}

Since its founding, NASA has been dedicated to the advancement of aeronautics and space science. The NASA Scientific and Technical Information (STI) program plays a key part in helping NASA maintain this important role.

The NASA STI Program operates under the auspices of the Agency Chief Information Officer. It collects, organizes, provides for archiving, and disseminates NASA's STI. The NASA STI program provides access to the NASA Aeronautics and Space Database and its public interface, the NASA Technical Reports Server, thus providing one of the largest collections of aeronautical and space science STI in the world. Results are published in both non-NASA channels and by NASA in the NASA STI Report Series, which includes the following report types:

- TECHNICAL PUBLICATION. Reports of completed research or a major significant phase of research that present the results of NASA programs and include extensive data or theoretical analysis. Includes compilations of significant scientific and technical data and information deemed to be of continuing reference value. NASA counterpart of peer-reviewed formal professional papers but has less stringent limitations on manuscript length and extent of graphic presentations.

- TECHNICAL MEMORANDUM. Scientific and technical findings that are preliminary or of specialized interest, e.g., quick release reports, working papers, and bibliographies that contain minimal annotation. Does not contain extensive analysis.

- CONTRACTOR REPORT. Scientific and technical findings by NASA-sponsored contractors and grantees.
- CONFERENCE PUBLICATION. Collected papers from scientific and technical conferences, symposia, seminars, or other meetings sponsored or cosponsored by NASA.

- SPECIAL PUBLICATION. Scientific, technical, or historical information from NASA programs, projects, and missions, often concerned with subjects having substantial public interest.

- TECHNICAL TRANSLATION. Englishlanguage translations of foreign scientific and technical material pertinent to NASA's mission.

Specialized services also include creating custom thesauri, building customized databases, organizing and publishing research results.

For more information about the NASA STI program, see the following:

- Access the NASA STI program home page at http://www.sti.nasa.gov

- E-mail your question via the Internet to help@sti.nasa.gov

- Fax your question to the NASA STI Help Desk at 301-621-0134

- Telephone the NASA STI Help Desk at 301-621-0390

- Write to: NASA Center for AeroSpace Information (CASI) 7115 Standard Drive Hanover, MD 21076-1320 


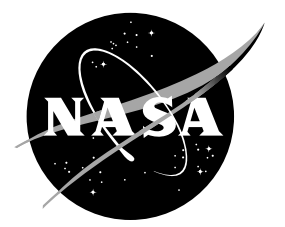

\section{Thermal Analysis on Cryogenic Liquid Hydrogen Tank on an Unmanned Aerial Vehicle System}

Xiao-Yen Wang, George Harpster, and James Hunter

Glenn Research Center, Cleveland, Ohio

Prepared for the

45th Aerospace Sciences Meeting and Exhibit

sponsored by the American Institute of Aeronautics and Astronautics

Reno, Nevada, January 8-11, 2007

National Aeronautics and

Space Administration

Glenn Research Center

Cleveland, Ohio 44135 


\section{Acknowledgments}

This NASA Low Emissions Alternative Power (LEAP) Project of the Vehicle Systems Program has supported this work. The first author greatly appreciates the valuable help received from Robert Buehrle and James Yuko.

Furthermore, the first author is grateful to Hung Huynh for reviewing this paper.

This report is a formal draft or working paper, intended to solicit comments and ideas from a technical peer group.

This report contains preliminary findings, subject to revision as analysis proceeds.

Level of Review: This material has been technically reviewed by technical management.

Available from

NASA Center for Aerospace Information 7115 Standard Drive

Hanover, MD 21076-1320
National Technical Information Service 5285 Port Royal Road Springfield, VA 22161 


\title{
Thermal Analysis on Cryogenic Liquid Hydrogen Tank on an Unmanned Aerial Vehicle System
}

\author{
Xiao-Yen Wang, George Harpster, and James Hunter \\ National Aeronautics and Space Administration \\ Glenn Research Center \\ Cleveland, Ohio 44135
}

\begin{abstract}
Thermal analyses are performed on the liquid hydrogen $\left(\mathrm{LH}_{2}\right)$ tank designed for an unmanned aerial vehicle (UAV) powered by solar arrays and a regenerative proton-exchange membrane (PEM) fuel cell. A 14-day cruise mission at a $65,000 \mathrm{ft}$ altitude [1] is considered. Thermal analysis provides the thermal loads on the tank system and the boiling-off rates of $\mathrm{LH}_{2}$. Different approaches are being considered to minimize the boiling-off rates of the $\mathrm{LH}_{2}$. It includes an evacuated multilayer insulation (MLI) versus aerogel insulation on the $\mathrm{LH}_{2}$ tank and aluminum versus stainless steel spacer rings between the inner and outer tank. The resulting boiling-off rates of $\mathrm{LH}_{2}$ provided by the one-dimensional model and three-dimensional finite element analysis (FEA) on the tank system are presented and compared to validate the results of the three-dimensional FEA results. It concludes that heat flux through penetrations by conduction is as significant as that through insulation around the tank. The tank system with MLI insulation and stainless steel spacer rings results in the lowest boiling-off rate of $\mathrm{LH}_{2}$.
\end{abstract}

\section{Introduction}

The densified propellant $\left(\mathrm{LH}_{2}\right)$ is stored at cryogenic conditions near its boiling point. Any heat transferring into the propellant could cause phase change such that the storage of the propellant becomes more unmanageable and unpredictable. Heat leaks into the storage tank must be minimized through proper insulation. Boiling-off rate of the propellant in the storage system has to be assessed. For a 14-day mission, minimizing the boiling-off rate of $\mathrm{LH}_{2}$ could reduce the system mass significantly. Both an evacuated MLI blanket and aerogel insulation are investigated for comparison. An evacuated MLI blanket gives better thermal insulation; however, the MLI fabrication and installation requires extreme care and precision. In addition, the thermal performance of MLI is very sensitive to the vacuum pressure [2].

A representative $\mathrm{LH}_{2}$ tank system is shown in Fig. 1. It consists of two concentric spherical tanks connected by spacer rings, which serve as a sleeve bearing for the support rod passing through the tank assembly. The inner tank is welded to the support rod, and the two rings are welded to both inner and outer tanks to seal the vacuum gap between the tanks where either MLI or aerogel insulation is used. The inner tank has an $8.5 \mathrm{ft}$ diameter with a $0.031 \mathrm{in}$. thickness and holds $1,300 \mathrm{lbm}$ of $\mathrm{LH}_{2}$ stored at an internal pressure of 30 psia with $5 \%$ ullage. The outer tank is 0.25 in. thick and the MLI insulation is approximately 2 in. thick. The support rod has a 4 in. inner diameter with a $0.1 \mathrm{in}$. thickness while the ring has a $4.5 \mathrm{in}$. inner diameter with the same thickness. The support and inner/outer tanks are made of 2014-T6 aluminum and the spacer ring material is either 2014-T6 aluminum or stainless steel for comparison of heat loss.

In the following, the one-dimensional thermal circuit for the tank system is presented first, which is followed by the three-dimensional FEA on the tank system and conclusions. 


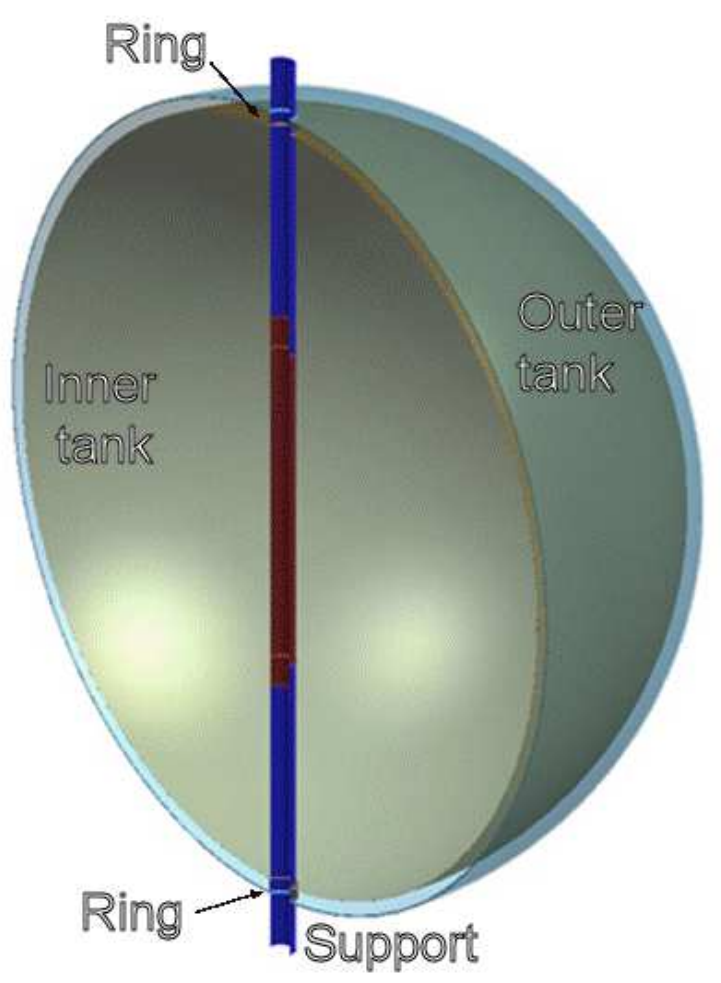

(a) Cutaway view

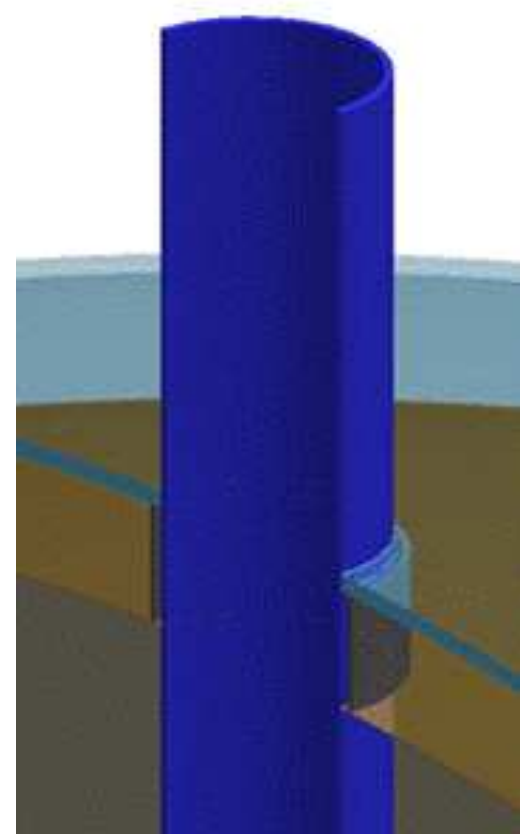

(b) Tank/rod interface detail

Figure 1. A representative $\mathrm{LH}_{2}$ tank design (courtesy of Timothy Roach).

\section{One-dimensional Thermal Circuit for the Tank System}

The heat transfer modes across the tank wall are sketched in Fig. 2, showing free convection and radiation outside the outer tank and free convection inside the inner tank. Note that the wall thickness of both the inner and outer tanks is ignored due to the relatively thin wall. Between the inner tank and outer tank, heat flux transfers through three parallel paths, which shows conduction through two rings and MLI/aerogel insulation. Across the evacuated MLI or aerogel insulation, both radiation and conduction take place, which is not shown in Fig. 2. Either the effective thermal conductivity, $k_{e}$, or effective heat transfer coefficient, $h_{e}$, can be used to represent the evacuated MLI or aerogel insulation [3]. The equivalent thermal circuit is plotted in Fig. 3. $T_{a}$ and $T_{L H 2}$ are the temperatures of the ambient air and liquid hydrogen, respectively. The temperature of the inner and outer tanks is $T_{i}$ and $T_{o}$, respectively. Assuming the radius of the inner and outer tanks being $r_{1}$ and $r_{2}$, respectively, the thermal resistance between the outer tank and ambient, $R_{1}\left((\mathrm{~W} / \mathrm{K})^{-1}\right)$, is defined as

$$
R_{1}=\left[1 /\left(4 \pi r_{2}^{2} h_{1}\right)+1 /\left(4 \pi r_{2}^{2} \epsilon \sigma\left(T_{o}+T_{a}\right)\left(T_{o}^{2}+T_{a}^{2}\right)\right)\right]^{-1}
$$

where $h_{1}$ being the heat transfer coefficient(for convection mode), $\epsilon$ being the surface emissivity(for radiation mode), and $\sigma$ being the Stefan-Boltzmann constant $\left(\sigma=5.67 \times 10^{-8} \mathrm{~W} / \mathrm{m}^{2}-\mathrm{K}^{4}\right)$; the thermal resistance across the insulation annulus (MLI/aerogel), $R_{2}\left((\mathrm{~W} / \mathrm{K})^{-1}\right)$, is defined as

$$
R_{2}=1 /\left(4 \pi k_{e}\right)\left(1 / r_{1}-1 / r_{2}\right)
$$




\section{$\mathrm{T}_{\mathrm{a}}=216.7 \mathrm{~K}$ at $65,000 \mathrm{ft}$ altitude}

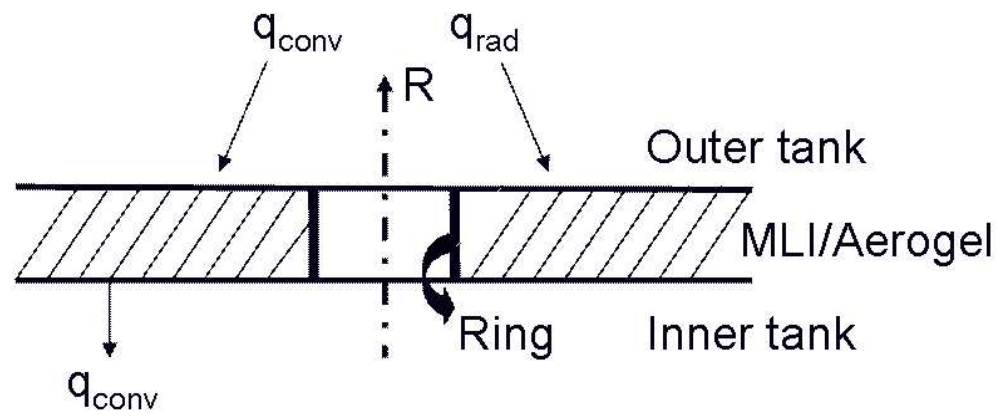

$$
\mathrm{T}_{\mathrm{LH} 2}=20.4 \mathrm{~K}
$$

Figure 2. Schematic view of the one-dimensional heat transfer across the tank wall.

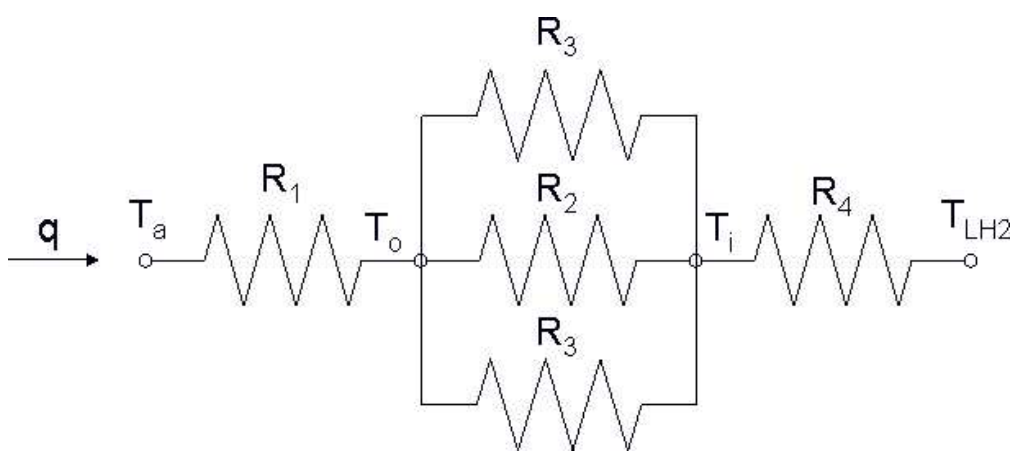

Figure 3. Equivalent thermal circuit across the tank wall.

the thermal resistance through the conduction (outer tank, ring, inner tank, and support), $R_{3}\left((\mathrm{~W} / \mathrm{K})^{-1}\right)$, is defined as

$$
R_{3}=\frac{1}{k_{1} A_{c, 1} / L_{1}}+\frac{1}{k_{2} A_{c, 2} / L_{2}}+\frac{1}{k_{3} A_{c, 3} / L_{3}}+\frac{1}{k_{4} A_{c, 4} / L_{4}}
$$

where $k_{n}, L_{n}, A_{c, n}$ with $n=1,2,3$, and 4 are the thermal conductivity, the length of conduction, and the contact surface area for the outer tank, the ring, the inner tank, and the support rod, respectively. The thermal resistance between hydrogen and the inner tank, $R_{4}\left((\mathrm{~W} / \mathrm{K})^{-1}\right)$, is defined as

$$
R_{4}=1 /\left(4 \pi r_{1}^{2} h_{4}\right)
$$

with $h_{4}$ being the heat transfer coefficient. The total thermal resistance of the circuit, $R\left((\mathrm{~W} / \mathrm{K})^{-1}\right)$, is

$$
R=R_{1}+R_{4}+\frac{1}{\frac{1}{R_{2}}+\frac{2}{R_{3}}}
$$

The heat flux, q (W), can be computed by using

$$
q=\left(T_{a}-T_{L H 2}\right) / R
$$

and the temperature of the inner and outer tank are

$$
T_{i}=T_{L H 2}+q R_{4}, \quad T_{o}=T_{a}-q R_{1}
$$


The heat flux transferring through $R_{2}$ and $R_{3}$, denoted as $q_{2}$ and $q_{3}$, respectively, are computed as

$$
q_{2}=\left(T_{o}-T_{i}\right) / R_{2}, \quad q_{3}=\left(T_{o}-T_{i}\right) / R_{3}
$$

The boiling-off rate of $\mathrm{LH}_{2}, M(\mathrm{~kg} / \mathrm{s})$, is computed by using

$$
M=q / h_{f g}
$$

Note that the heat flux to $\mathrm{LH}_{2}$ prior to phase change is ignored since the amount of heat is very small compared to the latent heat.

At a $65000 \mathrm{ft}$ altitude, the ambient air temperature is $-70^{\circ} \mathrm{F}(216.7 \mathrm{~K})$ and the pressure is 0.826 psia. The $\mathrm{LH}_{2}$ is filled in at a temperature of $20.4^{\circ} \mathrm{K}$. At a 30 psia internal pressure, the boiling temperature of $\mathrm{LH}_{2}$ is $23{ }^{\circ} \mathrm{K}$ and the latent heat, $h_{f g}$, is $428 \mathrm{~kJ} / \mathrm{kg}$. In Eq. (1), $h_{1}$ is chosen as $1 \mathrm{~W} / \mathrm{m}^{2}-\mathrm{K}$ by using the equation for free convection around a sphere [4], and $\epsilon=0.02$ for polished aluminum surface. In Eq. (2), $k_{e}=0.00016 \mathrm{~W} / \mathrm{m}-\mathrm{K}$ for MLI and $0.0017 \mathrm{~W} / \mathrm{m}-\mathrm{K}$ for aerogel [4]. In Eq. (3), $k_{2}=12.6 \mathrm{~W} / \mathrm{m}-\mathrm{K}$ for stainless steel AISI 304 and $163 \mathrm{~W} / \mathrm{m}-\mathrm{K}$ for aluminum, $L_{2}=2$ in. and $A_{c, 2}=0.44 \pi$ in. ${ }^{2}$, and $k_{1}=k_{3}=k_{4}=163$ $\mathrm{W} / \mathrm{m}-\mathrm{K}$ for aluminum inner and outer tanks and support rod. In Eq. (4), $h_{4}$ is chosen as $10 \mathrm{~W} / \mathrm{m}^{2}-\mathrm{K}$ based on the table data for free convection of liquid [4].

In the first case, it is assumed that no heat leak through the ring by conduction, that is, $R_{3}=\infty$. The heat flux and thermal resistance of the tank system is listed in Table 1. It can be seen that the thermal resistance between the hydrogen and inner tank and that between the ambient air and outer tank are very small. Replacing MLI with aerogel insulation, the thermal resistance, $R_{2}$, increases almost 10 times. The total heat flux is also increased almost 8 times. In the second case, it is assumed that the ring is made of stainless steel, the thermal resistance of the ring becomes dominant in $R_{3}$ and the resistance of aluminum tanks and support is negligible, which gives

$$
R_{3} \approx \frac{1}{k_{2} A_{c, 2} / L_{2}}
$$

The calculated results of the thermal resistances and heat flux for both MLI and aerogel insulation are listed in Table 2. It can be seen that the total heat flux is increased to $97.8 \mathrm{~W}$ from $13.3 \mathrm{~W}$ for MLI and to $217 \mathrm{~W}$ from $111 \mathrm{~W}$ for aerogel insulation. It is obvious that the heat loss through the penetration by conduction is significant. The total heat flux increases 7.35 times and $86 \%$ heat loss through the rings for MLI and 2 times and $38 \%$ heat leaks through the rings for aerogel. For the tank system with aluminum rings, the 1D result is not available due to the thermal resistances of the inner/outer tanks and supports can not be estimated, which will be investigated in the three-dimensional thermal analysis as follows.

\section{Three-dimensional FEA of the Tank System}

The tank system with MLI or aerogel insulation and aluminum or stainless steel spacer rings are analyzed using MSC Pthermal. A part of the finite element model of the tank system that has 73,494 nodes and 213,955 tetra elements is shown in Fig. 4. The free convection boundary condition is imposed on the inner surface of inner tank and the outer surface of the support inside the tank. The heat transfer coefficient is chosen as $5 \mathrm{~W} / \mathrm{m}^{2}-\mathrm{K}$ for the gaseous hydrogen part and $10 \mathrm{~W} / \mathrm{m}^{2}-\mathrm{K}$ for the liquid hydrogen part based on the table data for free convection in [4]. The part of the support outside the tank is assumed to be adiabatic. Free convection and radiation boundary conditions are imposed on the outer surface of the outer tank in the same way as that in one-dimensional analysis. On the outer surface of the inner tank, the effective heat transfer coefficient, $h_{e}=k_{e} / t$ with $t$ being the thickness of the insulation, was used, and $h_{e}=0.00314 \mathrm{~W} / \mathrm{m}^{2}-\mathrm{K}$ for MLI and $0.03346 \mathrm{~W} / \mathrm{m}^{2}-\mathrm{K}$ for aerogel. There is no contact between the support and outer tank. In the case with the rings and support rod, the support and inner tank, the rings and inner/outer tanks are assumed to have no thermal resistance between each of them. Otherwise, larger thermal resistances are imposed at the 


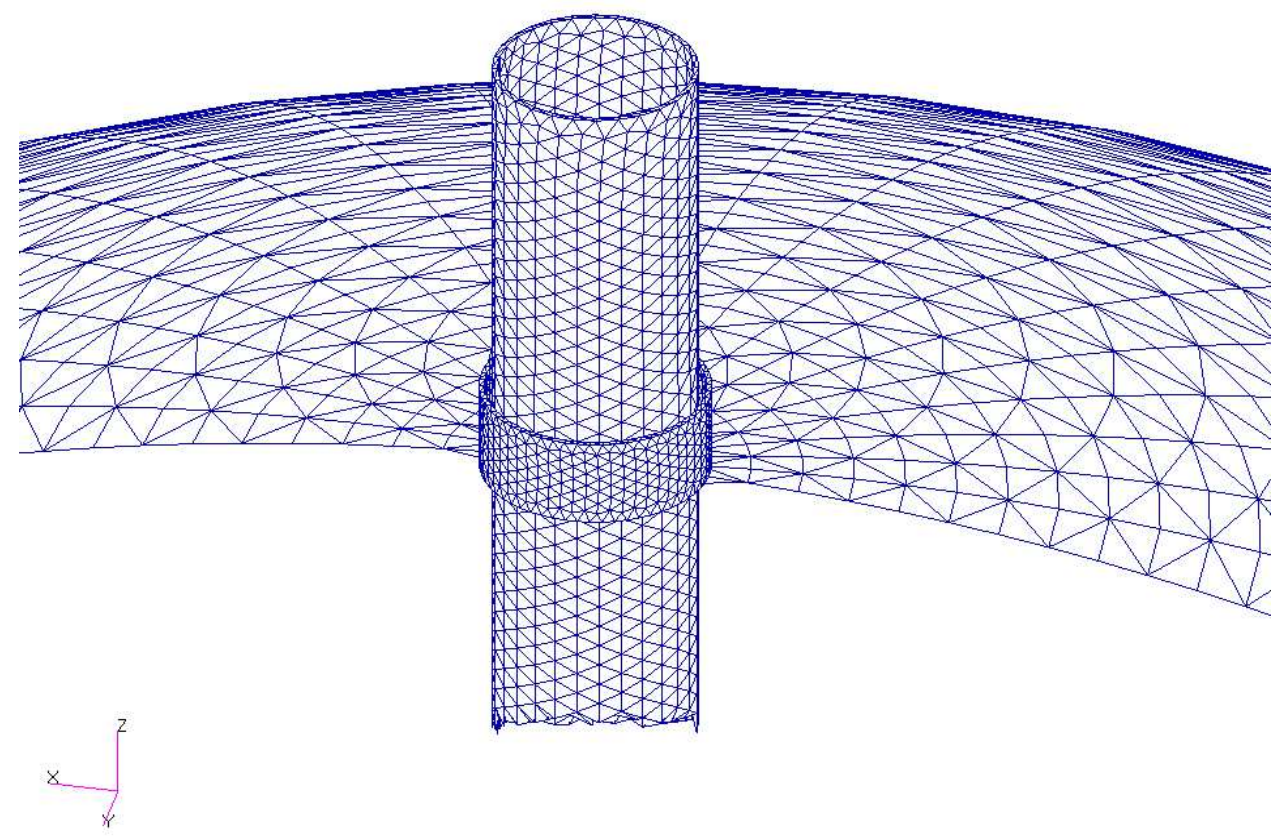

Figure 4. Part of the finite element model of the tank system.

interface to represent no heat transfer through there. Three cases including (i) without rings and support; (ii) with support and aluminum rings; and (iii) with support and stainless steel rings are considered here for both MLI and aerogel insulation.

To show the representative temperature distribution on the tank assembly, the MSC Pthermal results of the tank system with evacuated MLI blanket and aluminum spacer rings are plotted in Figs. 5 to 12 . The temperature contour for the tank system is shown in Fig. 5, showing that most part of the outer tank is almost as hot as the ambient and most of the inner tank is nearly as cold as the hydrogen. A large temperature gradient appears around the top and bottom areas where the support penetrates. The close view of the top area is shown in Fig. 6. It can be seen that the heat conducts from the hot outer tank to the connecting ring and the inner tank then goes to the support. The hottest spot on the top part of the support is located at the interface of the support and inner tank, showing a temperature of $126{ }^{\circ} \mathrm{K}$. The similar phenomena is seen at the bottom part plotted in Fig. 7. However, the bottom part has a lower temperature due to the contact with liquid hydrogen instead of gaseous hydrogen. The maximum temperature on the bottom part of the support is around $114{ }^{\circ} \mathrm{K}$. The top ring is around $10^{\circ} \mathrm{K}$ hotter than the bottom ring. The observation described above is further verified by the plots of the temperature contour on the top/bottom ring (together with part of the inner and outer tanks) in Figs. 8 and 9, and on the support (together with part of the inner tank) in Fig. 10. The temperature contour of the inner and outer tanks are plotted in Figs. 11 and 12, respectively, to show a clear view of the temperature distribution. The corresponding temperature contours for the tank system with aerogel insulation are plotted in Figs. 13 to 15 . The temperature distribution is very similar to those presented above for the tank system with evacuated MLI. However, the outer tank is much hotter and the inner tank is much cooler because much less heat transfers from the outer tank to the inner tank. The temperature distribution of the tank system with stainless steel spacer rings is very similar to that with aluminum spacer rings and is not plotted here.

The three-dimensional results of the total heat flux are listed and compared with the one-dimensional 
result in Table 3 for the three cases. For the system without a support and rings, the heat flux transferring into the $\mathrm{LH}_{2}$ is $16.5 \mathrm{~W}$ for MLI and $137 \mathrm{~W}$ for aerogel, which agrees well with the one-dimensional results that are $13.3 \mathrm{~W}$ and $111 \mathrm{~W}$, respectively. For the system with stainless steel rings, the total heat loss is 87.5 $\mathrm{W}$ for MLI and $213 \mathrm{~W}$ for aerogel, which is very close to the one-dimensional results that are $97.8 \mathrm{~W}$ and $217 \mathrm{~W}$. For the system with aluminum rings, the total heat flux $(237 \mathrm{~W})$ for MLI is 2.7 times of that with stainless steel rings, and while for aerogel, the heat flux $(354 \mathrm{~W})$ becomes 1.7 times. It can be concluded that the system with stainless steel spacer rings and MLI blanket results in the least heat flux. The corresponding boiling-off rate of $\mathrm{LH}_{2}, M$, is $1.62 \mathrm{lbm} / \mathrm{hr}$. For a 14-day mission, an extra $544 \mathrm{lbm}$ mass of $\mathrm{LH}_{2}$ has to be carried for boiling-off. However, the tank is designed to carry $1,300 \mathrm{lbm} \mathrm{LH}_{2}$ for the required power. With the total boiling-off mass of the $\mathrm{LH}_{2}$ within the 14-day mission being taken into an account, the vehicle can operate 8 to 9 days on $1,300 \mathrm{lbm} \mathrm{L_{2 }}$ instead of 14 days. The heat leak from the tank system with stainless steel rings and MLI blanket needs to be further reduced to minimize the boiling-off rate of $\mathrm{LH}_{2}$. A $81.1 \%$ of total heat loss still goes through the penetration by conduction. The ring between the inner and outer tank could be replaced with a bellows made of stainless steel to increase its thermal resistance. The support rod could be modified to have two separate parts located at the top and bottom parts of the tank and ended at the inner tank such that the heat transfer area between the support and hydrogen is greatly reduced. Other solutions that might be pursued to minimize the heat flux transferring to the hydrogen from the ambient are not the focus of this paper and will not be further discussed here.

\section{Conclusion}

The thermal analyses on the $\mathrm{LH}_{2}$ tank system used in an unmanned aerial vehicle were performed. Both one-dimensional thermal model and three-dimensional FEA results are presented and discussed. The computed results of the heat flux transferring to the tank system showed that the heat leak through penetrations are significant. For a 14-day mission, the current tank design with MLI insulation requires an extra 544 $\mathrm{lbm} \mathrm{LH}_{2}$ for boiling-off while the tank carries only $1,300 \mathrm{lbm} \mathrm{LH}$ for the required power. The vehicle can operate 8 to 9 days when taking into an account of the boiling-off of the $\mathrm{LH}_{2}$. The heat flux transferring to the tank system from the ambient has to be further reduced. The thermal resistance between the inner and outer tanks should be maximized by reducing the contact surface area between the ring and the inner/outer tank and by replacing the ring with a bellows made of stainless steel if it is possible.

\section{References}

\footnotetext{
${ }^{1}$ Sullivan, R., et. al, Engineering Analysis Studies for Preliminary Design of Light Weight Cryogenic Hydrogen Tanks in UAV Applications, NASA TP-2006-214094, 2006.

${ }^{2}$ Colozza, A., Hydrogen Storage for Aircraft Applications Overview, NASA/CR-2002-211867.

${ }^{3}$ ESA-CR(P)-754, Vol. 2, Spacecraft Thermal Control Design Data, Vol. 2, Polytechnical University of Madrid (Spain).

${ }^{4}$ Incropera, F.P. and DeWitt, D.P., Fundamentals of Heat and Mass Transfer, John Wiley and Sons, 1990.
} 
Table 1. One-dimensional thermal results (without support and rings)

\begin{tabular}{c|c|c|c|c|c|c|c|}
\hline $\begin{array}{c}k_{e} \\
(\mathrm{~W} / \mathrm{m}-\mathrm{K})\end{array}$ & $\begin{array}{c}R_{1} \\
(\mathrm{~W} / \mathrm{K})^{-1}\end{array}$ & $\begin{array}{c}R_{2} \\
(\mathrm{~W} / \mathrm{K})^{-1}\end{array}$ & $\begin{array}{c}R_{3} \\
(\mathrm{~W} / \mathrm{K})^{-1}\end{array}$ & $\begin{array}{c}R_{4} \\
(\mathrm{~W} / \mathrm{K})^{-1}\end{array}$ & $\begin{array}{c}q \\
(\mathrm{~W})\end{array}$ & $\begin{array}{c}q_{2} \\
(\mathrm{~W})\end{array}$ & $\begin{array}{c}2 q_{3} \\
(\mathrm{~W})\end{array}$ \\
\hline $0.00016^{1}$ & 0.047 & 14.52 & $\infty$ & 0.0047 & 13.3 & 13.3 & 0 \\
\hline $0.0017^{2}$ & 0.030 & 1.37 & $\infty$ & 0.0047 & 111 & 111 & 0 \\
\hline
\end{tabular}

${ }^{1} \mathrm{MLI},{ }^{2}$ Aerogel

Table 2. One-dimensional thermal results (with support and stainless steel rings)

\begin{tabular}{c|c|c|c|c|c|c|c|}
\hline $\begin{array}{c}k_{e} \\
(\mathrm{~W} / \mathrm{m}-\mathrm{K})\end{array}$ & $\begin{array}{c}R_{1} \\
(\mathrm{~W} / \mathrm{K})^{-1}\end{array}$ & $\begin{array}{c}R_{2} \\
(\mathrm{~W} / \mathrm{K})^{-1}\end{array}$ & $\begin{array}{c}R_{3} \\
(\mathrm{~W} / \mathrm{K})^{-1}\end{array}$ & $\begin{array}{c}R_{4} \\
(\mathrm{~W} / \mathrm{K})^{-1}\end{array}$ & $\begin{array}{c}q \\
(\mathrm{~W})\end{array}$ & $\begin{array}{c}q_{2} \\
(\mathrm{~W})\end{array}$ & $\begin{array}{c}2 q_{3} \\
(\mathrm{~W})\end{array}$ \\
\hline 0.00016 & 0.047 & 14.52 & 4.52 & 0.0047 & 97.8 & 13.2 & 84.6 \\
\hline 0.0017 & 0.030 & 1.37 & 4.52 & 0.0047 & 217.0 & 135.1 & 81.9 \\
\hline
\end{tabular}

Table 3. Three-dimensional thermal results compared with the one-dimensional results

\begin{tabular}{c|c|c|c|c|c|}
\hline & \multicolumn{2}{|c|}{$\begin{array}{c}\text { Without support } \\
\text { and rings }\end{array}$} & \multicolumn{2}{c|}{$\begin{array}{c}\text { With support and } \\
\text { stainless steel rings }\end{array}$} & $\begin{array}{c}\text { With support and } \\
\text { aluminum rings }\end{array}$ \\
\hline $\begin{array}{c}k_{e} \\
\text { 3D FEA }\end{array}$ & $\begin{array}{c}1 \mathrm{D} \text { result } \\
\text { 3D FEA }\end{array}$ & $\begin{array}{c}\text { 1D result } \\
q(\mathrm{~W})\end{array}$ & $\begin{array}{c}\text { 3D FEA } \\
q(\mathrm{~W})\end{array}$ \\
\hline 0.00016 & 16.5 & 13.3 & 87.5 & 97.8 & 237 \\
\hline 0.0017 & 137 & 111 & 213 & 217 & 354 \\
\hline
\end{tabular}

MSC.Patran 2005 18-Oct-05 16:30:12

Fringe: TIME: $0.0000000000 \mathrm{D}+00$ SECONDS S.S. ITERATIONS: 7535, nr000.nrf01, Temperature, .. (NON-LAYERED)

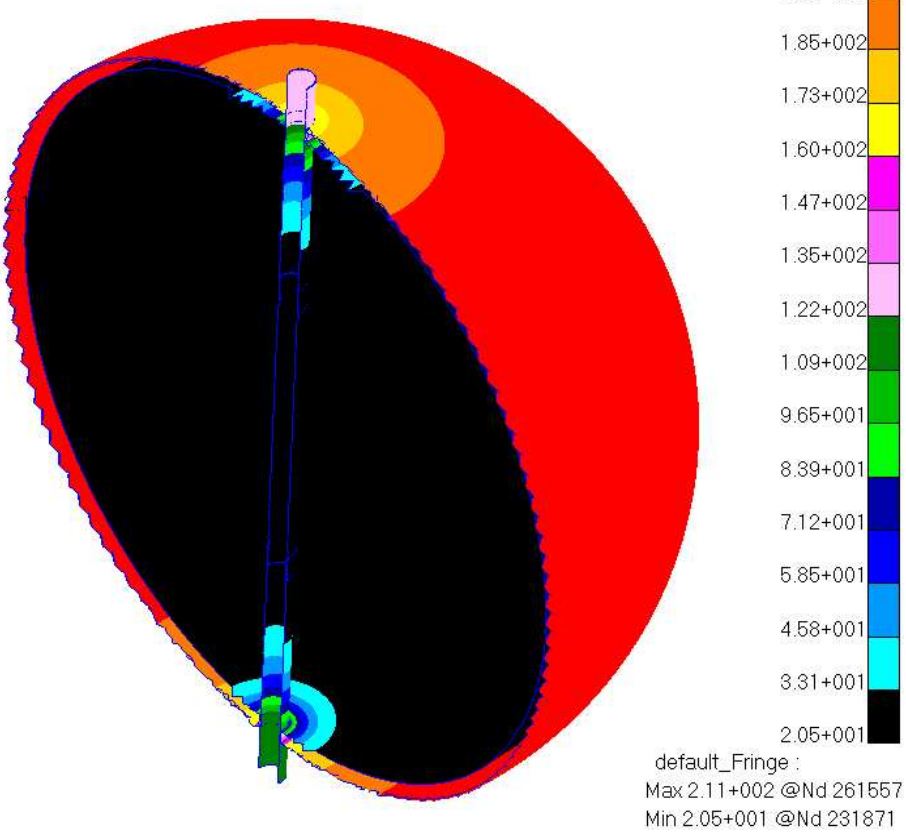

Figure 5. Temperature (K) contour on the tank system with MLI. 


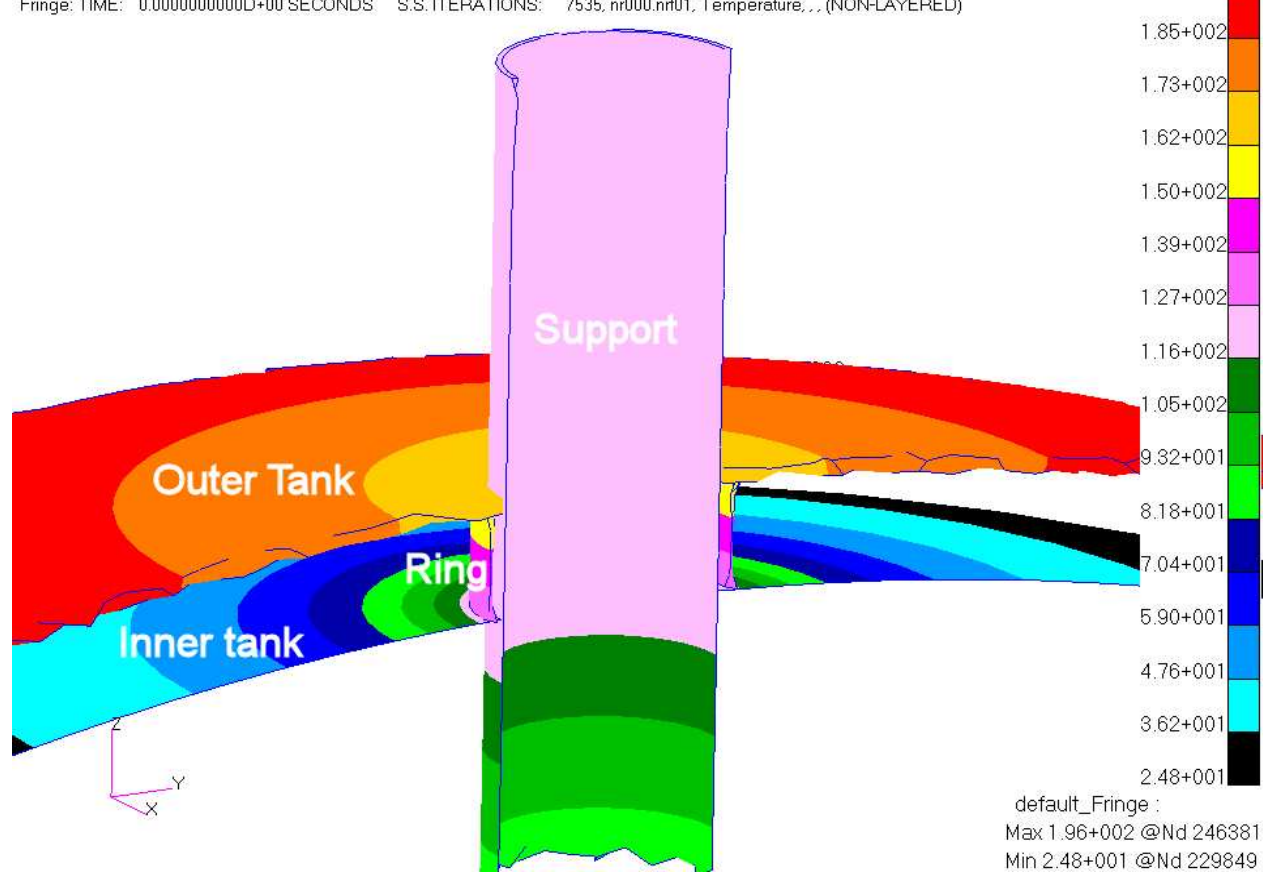

Figure 6. Close view of the top part of the tank system with MLI.

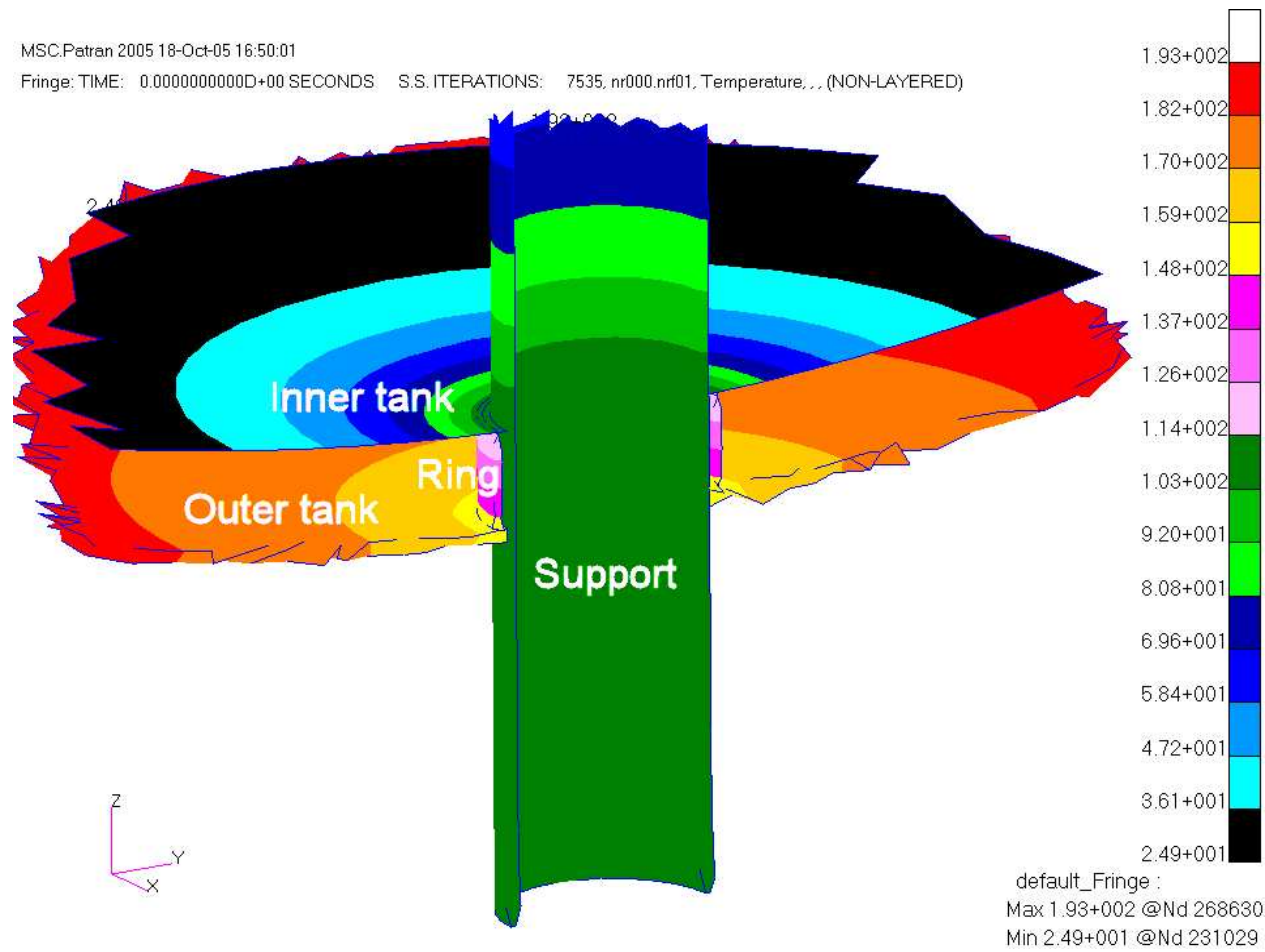

Figure 7. Close view of the bottom part of the tank system with MLI. 

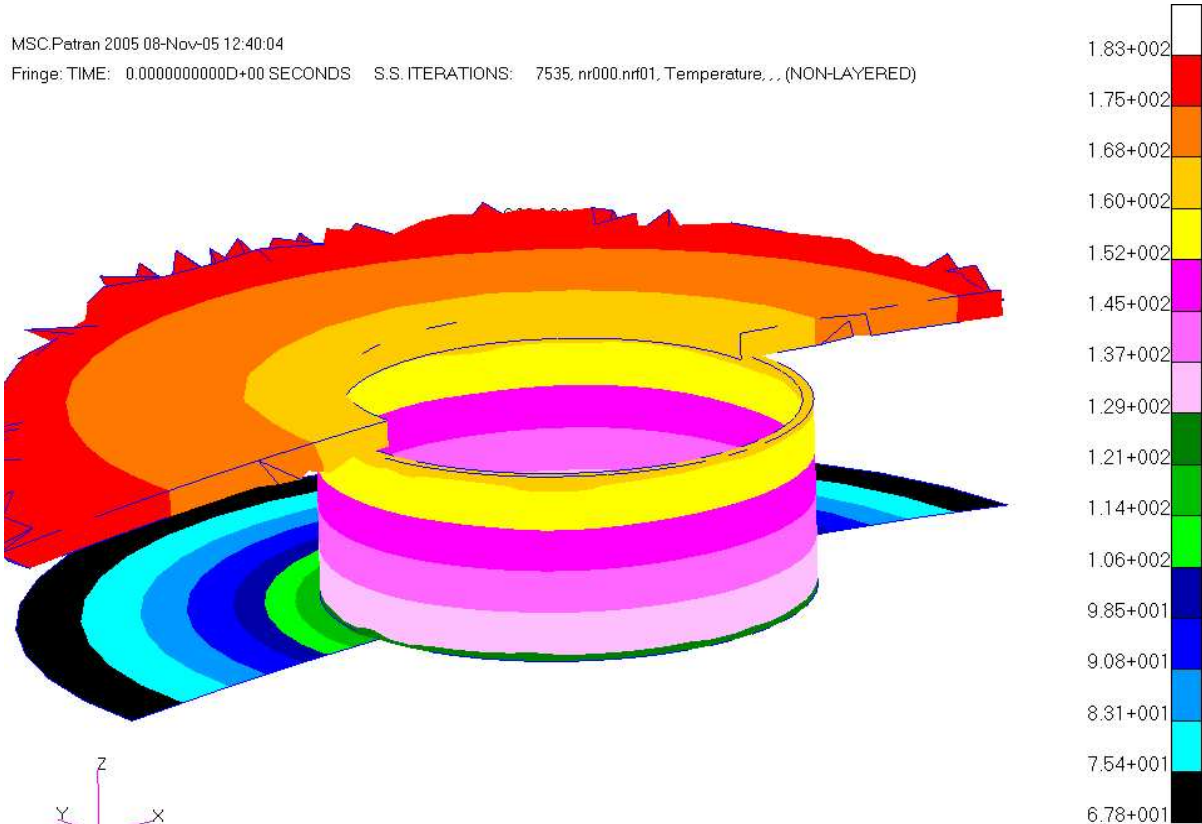

default_Fringe

Max $1.83+002 @ N d 245545$

Min6.78+001@Nd 228601

Figure 8. Temperature (K) contour of the top ring with part of the inner/outer tank (MLI).

\section{MSC.Patran 2005 08-Nov-05 12:50:15}

Fringe: TIME: $0.0000000000 \mathrm{D}+00$ SECONDS S.S. ITERATIONS: 7535, nr000.nrf01, Temperature, .. (NON-LAYERED)

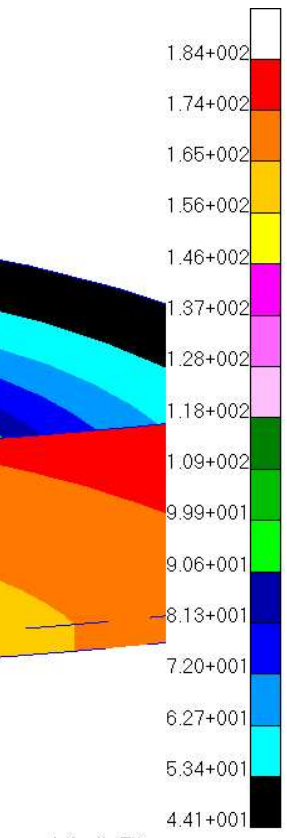

default_Fringe

$\operatorname{Max} 1.84+002 @ N d 237686$ Min 4.41+001@Nd 230915

Figure 9. Temperature (K) contour of the bottom ring with part of the inner/outer tank (MLI). 
MSC.Patran 2005 08-Nov-05 12:56:45

Fringe: TIME: $0.0000000000 \mathrm{D}+00$ SECONDS S.S. ITERATIONS: 7535, nr000.nrf01, Temperature,... (NON-LAYERED)

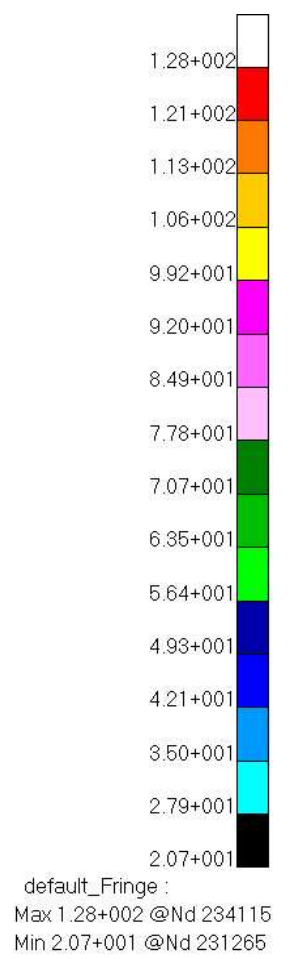

Figure 10. Temperature (K) contour of the support rod with part of the inner tank (MLI).

MSC.Patran 2005 18-Oct-05 16:12:36

Fringe: TIME: $0.0000000000 \mathrm{D}+00$ SECONDS S.S. ITERATIONS: 7535, nr000.nrfo1, Temperature, .. (NON-LAYERED)

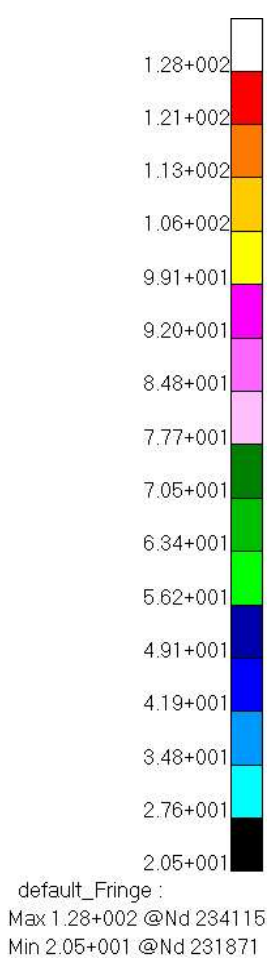

Figure 11. Temperature (K) contour of the inner tank (MLI). 
MSC.Patran 2005 18-Oct-05 16:01:10

Fringe: TIME: $0.0000000000 \mathrm{D}+00$ SECONDS S.S. ITERATIONS: 7535, nr000.nrf01, Temperature, .. (NON-LAYERED)

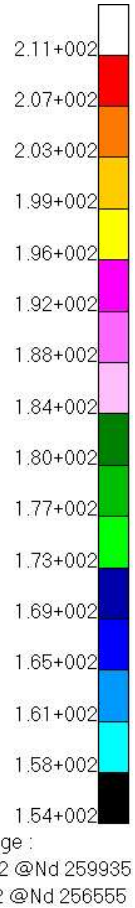

Figure 12. Temperature (K) contour of the outer tank (MLI).

MSC.Patran 2005 18-Oct-05 15:44:57

Fringe: TIME: $0.0000000000 \mathrm{D}+00$ SECONDS S.S. ITEPATIONS: 7406, nr000. nrf01, Temperature,... (NON-LAYERED)

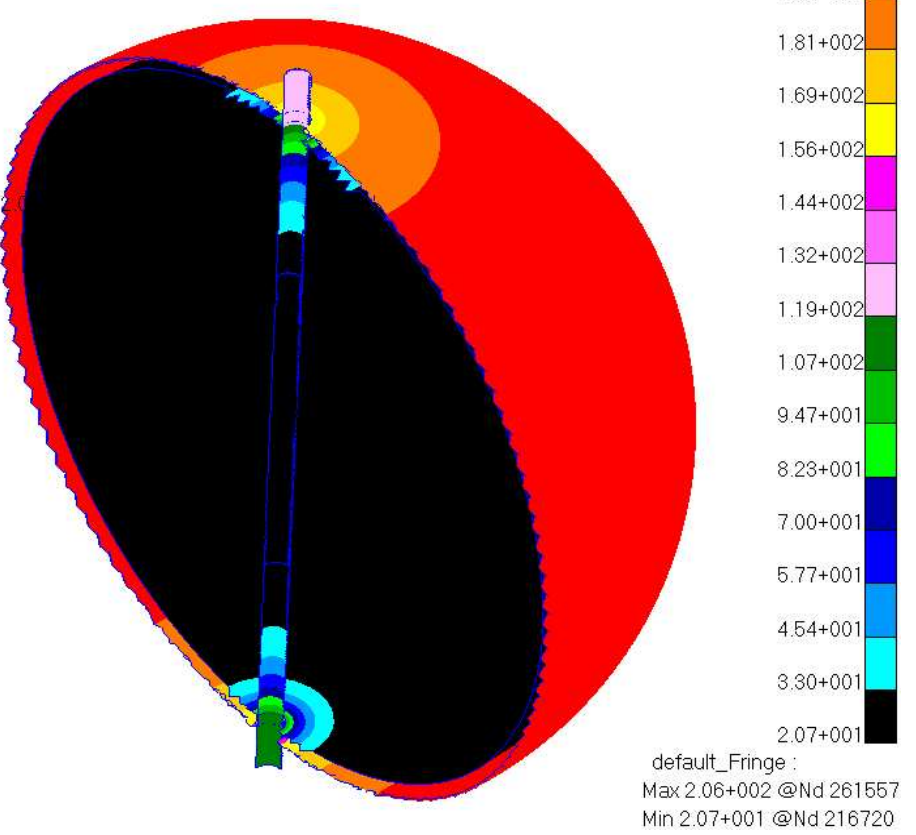

Figure 13. Temperature (K) contour on the tank system with aerogel insulation. 
MSC.Patran 2005 18-Oct-05 15:45:13

Fringe: TIME: $0.0000000000 \mathrm{D}+00$ SECONDS S.S. ITERATIONS: 7406, nr000.nrf01, Temperature, ... (NON-LAYERED)

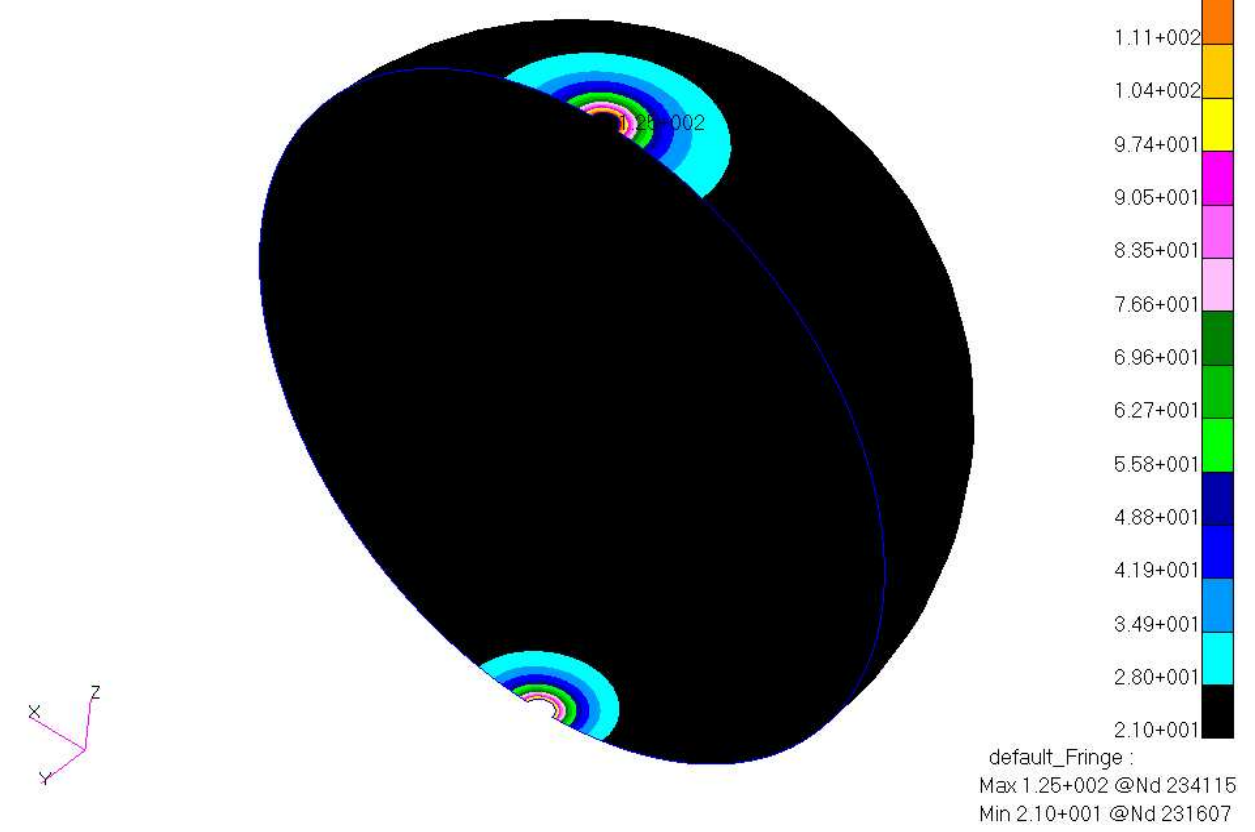

Figure 14. Temperature (K) contour of the inner tank (aerogel insulation).

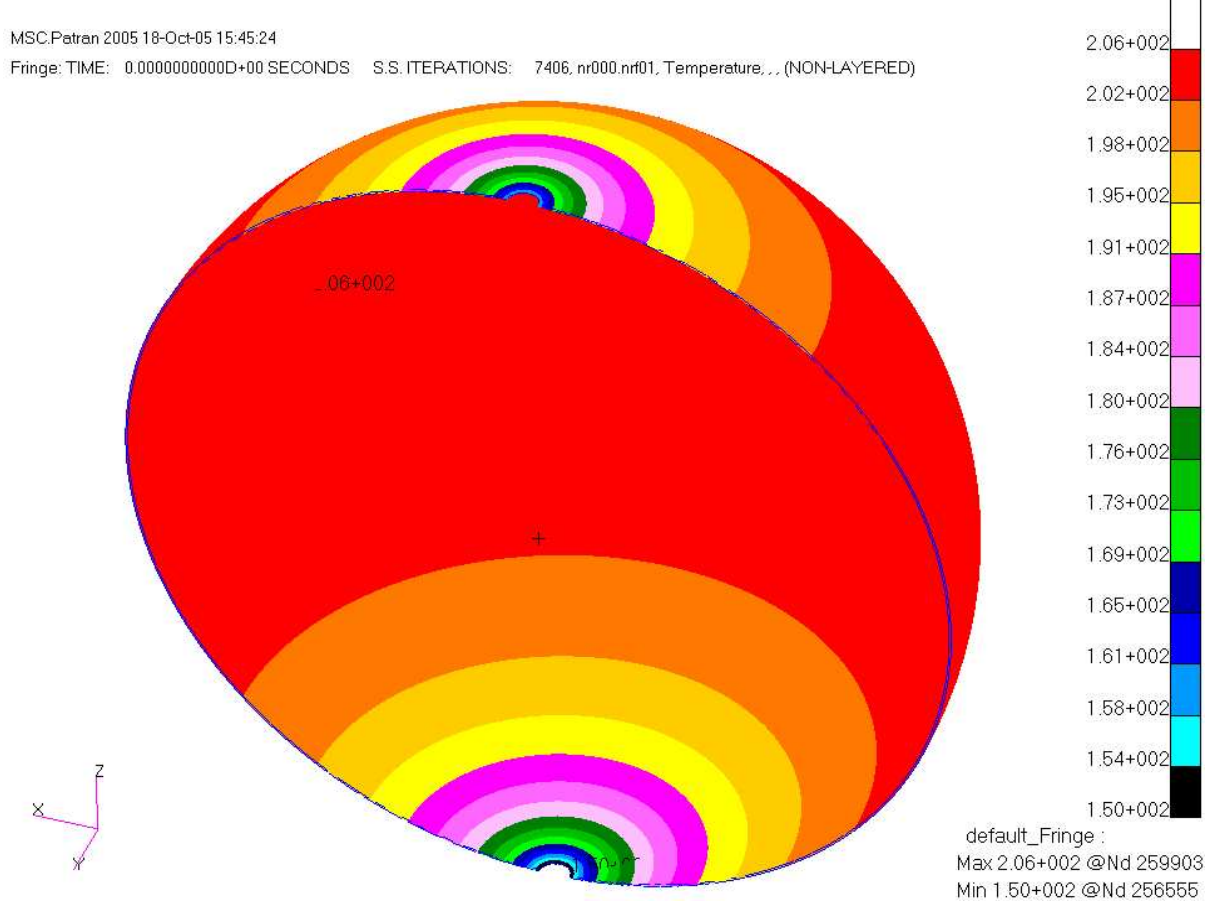

Figure 15. Temperature (K) contour of the outer tank (aerogel insulation). 
Public reporting burden for this collection of information is estimated to average 1 hour per response, including the time for reviewing instructions, searching existing data sources, gathering and maintaining the data needed, and completing and reviewing the collection of information. Send comments regarding this burden estimate or any other aspect of this collection of information, including suggestions for reducing this burden, to Washington Headquarters Services, Directorate for Information Operations and Reports, 1215 Jefferson Davis Highway, Suite 1204, Arlington, VA 22202-4302, and to the Office of Management and Budget, Paperwork Reduction Project (0704-0188), Washington, DC 20503.

\begin{tabular}{|l|l|l}
\hline 1. AGENCY USE ONLY (Leave blank) & $\begin{array}{c}\text { 2. REPORT DATE } \\
\text { January } 2007\end{array}$ & $\begin{array}{c}\text { 3. REPORT TYPE AND DATES COVERED } \\
\text { Technical Memorandum }\end{array}$
\end{tabular}

4. TITLE AND SUBTITLE

5. FUNDING NUMBERS

Thermal Analysis on Cryogenic Liquid Hydrogen Tank on an Unmanned Aerial

Vehicle System

6. $\operatorname{AUTHOR(S)}$

WBS 931164.03.01.02.01

Xiao-Yen Wang, George Harpster, and James Hunter

7. PERFORMING ORGANIZATION NAME(S) AND ADDRESS(ES)

National Aeronautics and Space Administration

John H. Glenn Research Center at Lewis Field

Cleveland, Ohio 44135-3191

8. PERFORMING ORGANIZATION REPORT NUMBER

E-15811

9. SPONSORING/MONITORING AGENCY NAME(S) AND ADDRESS(ES)

National Aeronautics and Space Administration

Washington, DC 20546-0001

10. SPONSORING/MONITORING AGENCY REPORT NUMBER

NASA TM-2007-214675

AIAA-2007-1218

\section{SUPPLEMENTARY NOTES}

Prepared for the 45th Aerospace Sciences Meeting and Exhibit sponsored by the American Institute of Aeronautics and Astronautics Reno, Nevada, January 8-11, 2007. Responsible person, Xiao-Yen Wang, organization code DEF, 216-433-2333.

12a. DISTRIBUTION/AVAILABILITY STATEMENT

12b. DISTRIBUTION CODE

Unclassified - Unlimited

Subject Category: 34

Available electronically at http://gltrs.grc.nasa.gov

This publication is available from the NASA Center for AeroSpace Information, 301-621-0390.

13. ABSTRACT (Maximum 200 words)

Thermal analyses are performed on the liquid hydrogen $\left(\mathrm{LH}_{2}\right)$ tank designed for an unmanned aerial vehicle (UAV) powered by solor arrays and a regenerative proton-exchange membrane (PEM) fuel cell. A 14-day cruise mission at a $65,000 \mathrm{ft}$ altitude is considered. Thermal analysis provides the thermal loads on the tank system and the boiling-off rates of $\mathrm{LH}_{2}$. Different approaches are being considered to minimize the boiling-off rates of the $\mathrm{LH}_{2}$. It includes an evacuated multilayer insulation (MLI) versus aerogel insulation on the $\mathrm{LH}_{2}$ tank and aluminum versus stainless steel spacer rings between the inner and outer tank. The resulting boil-off rates of $\mathrm{LH}_{2}$ provided by the one-dimensional model and three-dimensional finite element analysis (FEA) on the tank system are presented and compared to validate the results of the three-dimensional FEA. It concludes that heat flux through penetrations by conduction is as significant as that through insulation around the tank. The tank system with MLI insulation and stainless steel spacer rings result in the lowest boiling-off rate of $\mathrm{LH}_{2}$.

\begin{tabular}{|c|c|c|c|}
\hline \multicolumn{3}{|l|}{ 14. SUBJECT TERMS } & 15. NUMBER OF PAGES \\
\hline \multicolumn{3}{|c|}{ Thermal analysis; Cryogenic $\mathrm{LH}_{2}$} & 16. PRICE CODE \\
\hline $\begin{array}{l}\text { 17. SECURITY CLASSIFICATION } \\
\text { OF REPORT }\end{array}$ & $\begin{array}{l}\text { 18. SECURITY CLASSIFICATION } \\
\text { OF THIS PAGE }\end{array}$ & $\begin{array}{l}\text { 19. SECURITY CLASSIFICATION } \\
\text { OF ABSTRACT }\end{array}$ & 20. LIMITATION OF ABSTRACT \\
\hline Unclassified & Unclassified & Unclassified & \\
\hline
\end{tabular}



